\title{
痛風の主要病因遺伝子ABCG 2の同定
}

\begin{tabular}{|c|c|c|c|c|c|c|}
\hline 松尾 洋孝1) & 市田 & 公美(2) & 高田 & 龍平4) & 中村 & 好宏 \\
\hline 昌喜1) & 高田 & 雄三6) & 井上 & 寛規1) & 櫻井 & \\
\hline $\begin{array}{l}\text { 細谷 龍男 }{ }^{3)} \\
\text { 四/宮成祥 }{ }^{1)}\end{array}$ & 金井 & 好克 ${ }^{8}$ & 鈴木 & 洋史 ${ }^{4)}$ & 浜島 & \\
\hline
\end{tabular}

目的

痛風の主要病因遺伝子を同定するために, こ れまでのゲノムワイド連鎖解析などから有望な 候補遺伝子である ABCG 2に着目し，分子機能を 指標とした遺伝子解析を実施した。

\section{方 法}

分子機能解析として, 輸送機能はABCG 2を発 現した細胞から調整したベジクルを用いて実施 した.90名の高尿酸血症を対象に, ABCG 2遺伝 子の全コーディング領域のresequencingを実施し, 得られた候補変異による輸送機能の変化を評価 した，頻度の高い変異について，739名の健診サ ンプルを用いたQTL解析を実施した。さらに, 日本人男性の痛風症例 161 名を含む 228 名の高尿 酸血症症例之, 尿酸值が正常な日本人男性 865 名 を対象として主要な変異のタイピングとハプロ タイプ頻度解析などを行い, 予測される輸送機 能別の発症リスクを評価した。

\section{結果}

ABCG 2は, 高容量性の尿酸排泄トランスポー ターであった。高尿酸血症 90 名の解析で認めら れた6つのアミノ酸変化を伴う変異のうち, Q126Xを含む4つは機能消失型変異であった. Q141Kは機能が半減する変異であった。 QTL解 析により, ABCG 2の機能低下型変異により尿酸 值が有意に上昇することがわかり，ABCG 2の腎 臟，小腸などの発現パターンから， ABCG 2がこ れらの臓器からの尿酸排泄を司ることが示唆さ れた。特に頻度の高いQ126XとQ141Kを対象に ハプロタイプ頻度解析を実施したところ，これ らのリスク変異は独立し，1つのハプロタイプに 共存しないことがわかった。予測される輸送機 能別の発症リスクを評価すると, ABCG 2の機能 が1／4以下になる変異パターンは解析した痛風 症例の 1 割に認められ，発症リスクが 25.8 倍にな ることがわかつた．ABCG 2の機能が $1 / 2$ または 3/4になると発症リスクがそれぞれ4.34倍， 3.02 倍となり, ABCG 2の機能低下を認める痛風症例 は8割にもわたることがわかった。
1 ）防衛医科大学分子生体制御学

2 ) 東京薬科大学病態生理学

3 ) 東京慈恵会医科大学腎臓高血圧内科学

4) 東京大学医学部附属病院薬剂部

5 ) 防衛医科大学数学研究室

6 ) 防衛医科大学法医学

7 ) 防衛医科大学衛生学公衆衛生学

8 ）大阪大学医学部生体システム薬理学

9 ) 名古屋大学医学部予防医学 医学推計判断学
Hirotaka Matsuo, Akiyoshi Nakayama,

Hiroki Inoue and Nariyoshi Shinomiya

Kimiyoshi Ichida

Kimiyoshi Ichida, Tatsuo Hosoya

Tappei Takada, Hirofumi Suzuki

Yoshihiro Nakamura

Yuzo Takada

Hiroshi Sakurai

Yoshikatsu Kanai

Nobuyuki Hamashima 
考察

$\mathrm{ABCG}$ 2遺伝子のありふれた遺伝子変異パター ンの個人差が, 血液中の尿酸值および痛風発症 リスクの個人差につながることが明らかとなつ た。本研究により, 痛風の主要な病因遺伝子 $\mathrm{ABCG}$ 2が明らかとなり, ABCG 2の生理学的機 能が尿酸排泄を司ることが示唆された。 今後, 個人差に応じた新たな視点からの予防法や治療 薬の開発につながることが期待される.
文献

H. Matsuo, T. Takada, K. Ichida, T. Nakamura, et al. Sci. Transl. Med. 1, 5ra11 (2009). 